\title{
Neptunomonas concharum sp. nov., isolated from a dead ark clam, and emended description of the genus Neptunomonas
}

Correspondence

Jin-Woo Bae

baejw@khu.ac.kr

\author{
Hae-Won Lee, Na-Ri Shin, Jina Lee, Seong Woon Roh, Tae Woong Whon \\ and Jin-Woo Bae
}

Department of Life and Nanopharmaceutical Sciences and Department of Biology, Kyung Hee University, Seoul 130-701, Republic of Korea

\begin{abstract}
A novel Gram-staining-negative, facultatively anaerobic, motile and rod-shaped bacterium, designated strain LHW37 ${ }^{\top}$, was isolated from a dead ark clam collected on the south coast of Korea. The novel strain grew optimally at $37{ }^{\circ} \mathrm{C}$, at $\mathrm{pH} 7.0-8.0$ and with $2 \%(\mathrm{w} / \mathrm{v}) \mathrm{NaCl}$. The predominant cellular fatty acids were $C_{18: 1} \omega 7 c$ and summed feature $3\left(C_{16: 1} \omega 7 c\right.$ and/or iso$\left.\mathrm{C}_{15: 0} 2-\mathrm{OH}\right)$. The major isoprenoid quinone was ubiquinone-8 $(\mathrm{Q}-8)$ and the predominant polar lipids were phosphatidylethanolamine and phosphatidylglycerol. Phylogenetic analysis based on 16S rRNA gene sequences indicated that the novel strain was most closely related to Neptunomonas japonica JAMM $0745^{\top}$ ( $97.1 \%$ sequence similarity). The genomic DNA G $+\mathrm{C}$ content of strain LHW37 ${ }^{\top}$ was 48.2 mol\%. The DNA-DNA relatedness values recorded in hybridization experiments between the novel strain and its closest known relative were $\leqslant 18 \%$. Based on the phenotypic, genotypic and phylogenetic data, strain LHW37 ${ }^{\top}$ represents a novel species belonging to the genus Neptunomonas for which the name Neptunomonas concharum sp. nov. is proposed. The type strain is $\mathrm{LHW}^{\top} 7^{\top}\left(=\mathrm{KACC} 15543^{\top}=\mathrm{JCM} 17730^{\top}\right)$. An emended description of the genus Neptunomonas is also provided.
\end{abstract}

The genus Neptunomonas, within the family Oceanospirillaceae, was first described by Hedlund et al. (1999) to accommodate a species of marine bacterium that degrades polycyclic aromatic hydrocarbons. At the time of writing, three species found in marine sediment or aquatic environments are included within the genus: Neptunomonas naphthovorans (Hedlund et al., 1999), Neptunomonas antarctica (Zhang et al., 2010) and Neptunomonas japonica (Miyazaki et al., 2008). All are Gram-stainingnegative, aerobic, motile microbes that contain Q-8 as the major ubiquinone. A novel Neptunomonas-like bacterium, designated strain LHW $37^{\mathrm{T}}$, was isolated during a study of the bacterial community within an ark clam farm in South Korea. The taxonomic position of this novel strain has now been investigated by following a polyphasic approach.

Strain LHW $37^{\mathrm{T}}$ was isolated from a dead ark clam collected from a cage-cultured ark clam farm in Gang-jin bay, South Korea. The soft tissues of the dead clam were homogenized and diluted with sterile PBS. The diluted sample was then spread on plates of pleuropneumonia-like organisms agar (PPLOA; BBL) and incubated at $37^{\circ} \mathrm{C}$. Strain LHW $37^{\mathrm{T}}$ was isolated from one of these plates and then repeatedly

The GenBank/EMBL/DDBJ accession number for the $16 \mathrm{~S}$ rRNA gene sequence of strain $\mathrm{LHW}^{\top} 7^{\top}$ is JF748732.

A supplementary figure is available with the online version of this paper. subcultured under aerobic conditions, on marine agar (MA; BBL) at $37{ }^{\circ} \mathrm{C}$, to obtain a pure culture. The isolate was then suspended in marine broth (MB; BBL) containing $40 \%(\mathrm{v} / \mathrm{v})$ glycerol and stored at $-80{ }^{\circ} \mathrm{C}$.

Growth at different temperatures $(4,10,15,20,25,30$, 37,45 and $65{ }^{\circ} \mathrm{C}$ ) was examined in $\mathrm{MB}$. Growth at $\mathrm{pH} 4.0-11.0$ (at intervals of $1.0 \mathrm{pH}$ unit) was investigated in the same medium, with the pH adjusted using $10 \mathrm{mM}$ MES (pH 4-6), $10 \mathrm{mM}$ TAPS (pH 7-9) or $10 \mathrm{mM}$ $\mathrm{Na}_{2} \mathrm{HPO}_{4}(\mathrm{pH} 10-11)$. Growth with $0,1,2,3,4,5,8,10$, 12,15 and $20 \%(\mathrm{w} / \mathrm{v}) \mathrm{NaCl}$ was investigated in a medium made using the formula for $\mathrm{NaCl}$-free $\mathrm{MB}$. The optical density at $600 \mathrm{~nm}$ of each culture was measured, in a Synergy Mx spectrophotometer (BioTek) after incubation for $6,12,24$ and $48 \mathrm{~h}$ and 7 days. Gram staining was performed using a Gram staining kit (bioMérieux) according to the manufacturer's instructions. The morphologies of the colonies and cells were determined after incubation for 2 days on MA at $37{ }^{\circ} \mathrm{C}$. Cell morphology was investigated under a light microscope (Eclipse 50i; Nikon). Motility tests were conducted in semi-solid MA (Tittsler \& Sandholzer, 1936). Anaerobic growth on MA was determined after incubation at $37{ }^{\circ} \mathrm{C}$ for 7 days in an anaerobic chamber filled with $\mathrm{N}_{2} / \mathrm{CO}_{2} / \mathrm{H}_{2}(90: 5: 5$, by vol.). Strain LHW $37^{\mathrm{T}}$ grew at $\mathrm{pH}$ 6.0-10.0 (optimum pH 7.0-8.0), at $10-45{ }^{\circ} \mathrm{C}$ (optimum $37{ }^{\circ} \mathrm{C}$ ), and with $1-8 \%(\mathrm{w} / \mathrm{v}) \mathrm{NaCl}$ 
Table 1. Differential biochemical and physiological characteristics of strain LHW3 $7^{\top}$ and established species in the genus Neptunomonas

Strains: 1 , LHW $37^{\mathrm{T}} ; 2$, N. japonica JAMM $0745^{\mathrm{T}} ; 3$, N. antarctica S3$22^{\mathrm{T}} ; 4$, Neptunomonas naphthovorans NAG-2N-126 ${ }^{\mathrm{T}}$. All data are from this study unless stated otherwise. All four strains were positive for the assimilation of stachyose, acetic acid, $\alpha$-ketovaleric acid and succinic acid monomethyl ester (on GN2 MicroPlates), for acid production from D-tagatose and 5-ketogluconate (on API 50CHB/E test strips) and for alkaline phosphatase, leucine arylamidase and naphthol-AS-BI-phosphohydrolase activities (on API ZYM test strips). +, Positive; -, negative; ND, no data.

\begin{tabular}{|c|c|c|c|c|}
\hline Characteristic & 1 & 2 & 3 & 4 \\
\hline \multicolumn{5}{|l|}{ Growth temperature $\left({ }^{\circ} \mathrm{C}\right)$} \\
\hline Range & $10-45$ & $5-25^{\star}$ & $4-25 \dagger$ & $4-24 \ddagger$ \\
\hline Optimum & 37 & $20^{*}$ & $15 \dagger$ & ND \\
\hline \multicolumn{5}{|l|}{$\mathrm{NaCl}$ for growth $(\%, w / v)$} \\
\hline Range & $1.0-8.0$ & $1.0-5.0^{*}$ & $0.5-5.0 \dagger$ & $1.8-7.0 \ddagger$ \\
\hline Optimum & 2 & $2^{*}$ & $2-3 \dagger$ & $\mathrm{ND}$ \\
\hline \multicolumn{5}{|l|}{ Growth pH } \\
\hline Range & $6.0-10.0$ & $7.0-8.5^{\star}$ & $6.0-8.0 \dagger$ & $6.5-8.5 \neq$ \\
\hline Optimum & $7.0-8.0$ & $7.5^{\star}$ & $6.5-7.0 \dagger$ & $7.5 \ddagger$ \\
\hline \multicolumn{5}{|l|}{ Enzyme activity } \\
\hline DNase & + & + & - & - \\
\hline Esterase lipase (C8) & - & - & + & + \\
\hline Acid phosphatase & + & + & $-(+\dagger)$ & + \\
\hline $\begin{array}{l}\text { Reduction of nitrates to } \\
\text { nitrites }\end{array}$ & + & $-\left(+^{\star}\right)$ & + & $+(一 \ddagger)$ \\
\hline Indole production & - & - & - & + \\
\hline Glucose fermentation & + & + & - & - \\
\hline Gelatin hydrolysis & + & $-\left(+^{\star}\right)$ & - & - \\
\hline \multicolumn{5}{|l|}{ Acid production from: } \\
\hline D-Arabinose & + & - & - & - \\
\hline L-Arabinose & + & - & - & - \\
\hline D-Ribose & + & + & - & + \\
\hline D-Xylose & + & - & - & - \\
\hline L-Xylose & + & - & - & - \\
\hline D-Fructose & + & - & $-(+\dagger)$ & - \\
\hline L-Sorbose & + & - & - & - \\
\hline Aesculin & + & + & - & - \\
\hline Salicin & + & - & - & - \\
\hline Turanose & + & - & - & - \\
\hline D-Lyxose & + & - & - & + \\
\hline 2-Ketogluconate & - & - & + & - \\
\hline \multicolumn{5}{|l|}{ Assimilation of: } \\
\hline Inulin & + & - & + & - \\
\hline $\begin{array}{l}N \text {-Acetyl- } \beta \text {-D- } \\
\text { mannosamine }\end{array}$ & - & - & - & + \\
\hline D-Arabitol & - & - & - & + \\
\hline Cellobiose & - & - & - & + \\
\hline L-Fucose & - & - & - & + \\
\hline$\alpha$-D-Glucose & - & - & - & + \\
\hline Melibiose & - & - & - & + \\
\hline 3-Methyl D-glucose & + & - & + & + \\
\hline Methyl $\alpha$-D-glucoside & - & - & - & + \\
\hline Methyl $\beta$-D-glucoside & + & + & - & + \\
\hline Methyl $\alpha$-D-mannoside & - & - & - & + \\
\hline
\end{tabular}

Table 1. cont.

\begin{tabular}{|c|c|c|c|c|}
\hline Characteristic & 1 & 2 & 3 & 4 \\
\hline Palatinose & - & - & - & + \\
\hline L-Rhamnose & - & - & - & + \\
\hline D-Ribose & - & - & - & + \\
\hline D-Sorbitol & - & - & - & + \\
\hline Turanose & - & + & - & + \\
\hline Xylitol & - & + & + & + \\
\hline$\beta$-Hydroxybutyric acid & + & + & - & + \\
\hline$\gamma$-Hydroxybutyric acid & - & - & - & + \\
\hline$p$-Hydroxyphenylacetic acid & - & - & - & + \\
\hline Lactamide & - & - & - & + \\
\hline D-Lactic acid methyl ester & - & - & + & + \\
\hline D-Malic acid & - & - & + & - \\
\hline L-Malic acid & + & + & - & + \\
\hline Pyruvic acid methyl ester & + & - & - & + \\
\hline Propionic acid & - & - & - & + \\
\hline Pyruvic acid & - & - & - & + \\
\hline Succinamic acid & + & - & - & + \\
\hline $\mathrm{N}$-Acetyl-L-glutamic acid & + & - & - & + \\
\hline L-Alanyl glycine & + & + & - & - \\
\hline L-Asparagine & + & + & + & - \\
\hline L-Glutamic acid & + & - & - & + \\
\hline Glycyl L-glutamic acid & + & + & - & - \\
\hline L-Serine & - & - & + & - \\
\hline Putrescine & - & + & - & - \\
\hline 2,3-Butanediol & - & - & - & + \\
\hline Glycerol & - & + & - & + \\
\hline $2^{\prime}$-Deoxyadenosine & - & - & - & + \\
\hline Uridine & - & + & - & - \\
\hline D-Fructose 6-phosphate & - & - & - & + \\
\hline
\end{tabular}

${ }^{\star}$ Data from Miyazaki et al. (2008).

$\dagger$ Data from Zhang et al. (2010).

$\ddagger$ Data from Hedlund et al. (1999).

(optimum 2\%). The cells were motile, Gram-stainingnegative rods $(1.0-1.2 \times 0.5-0.6 \mu \mathrm{m})$. After 2 days on MA at $37^{\circ} \mathrm{C}$, strain LHW $37^{\mathrm{T}}$ formed cream-coloured, circular, smooth and convex colonies. Growth occurred under anaerobic conditions.

Oxidase and catalase activity were evaluated using $1 \%(\mathrm{v} /$ v) p-tetramethyl phenylenediamine (bioMérieux) and $3 \%$ (w/v) $\mathrm{H}_{2} \mathrm{O}_{2}$, respectively. DNase activity and $\mathrm{H}_{2} \mathrm{~S}$ production were tested on DNase test agar (BBL) and Kligler's iron agar (BBL), respectively. Acid production was tested using API $50 \mathrm{CH}$ strips (bioMérieux) with $50 \mathrm{CHB} / \mathrm{E}$ medium (bioMérieux), according to the manufacturer's instructions. Sole carbon source assimilation was determined using GN2 MicroPlates (Biolog) and inoculating fluid (Biolog) supplemented with $4 \%(\mathrm{w} / \mathrm{v})$ sea salts (Sigma-Aldrich), according to the manufacturer's instructions. API 20NE and API ZYM strips (bioMérieux) were used to characterize enzyme activity, again according to the manufacturer's instructions. Strain LHW $37^{\mathrm{T}}$ was found to 
be catalase-, oxidase- and DNase-positive but negative for $\mathrm{H}_{2} \mathrm{~S}$ production. Acid was produced from D-arabinose, Larabinose, D-ribose, D-xylose, L-xylose, D-fructose, L-sorbose, aesculin, salicin, turanose, D-lyxose, D-tagatose and potassium 5-ketogluconate (API 50CHB). Inulin, 3-methyl glucose, methyl $\beta$-D-glucoside, stachyose, acetic acid, $\beta$ hydroxybutyric acid, $\alpha$-ketovaleric acid, L-malic acid, pyruvic acid methyl ester, succinic acid monomethyl ester, succinamic acid, $\mathrm{N}$-acetyl-L-glutamic acid, L-alanyl glycine, L-asparagine, L-glutamic acid and glycyl L-glutamic acid were all assimilated (GN2 MicroPlate). In API ZYM tests, the novel strain was positive for alkaline phosphatase, leucine arylamidase, acid phosphatase and naphthol-AS-BIphosphohydrolase activities but negative for esterase (C4), esterase lipase (C8), lipase (C14), valine arylamidase, cystine arylamidase, trypsin, $\alpha$-chymotrypsin, $\alpha$-galactosidase, $\beta$-galactosidase, $\beta$-glucuronidase, $N$-acetyl- $\beta$-glucosaminidase, $\alpha$ mannosidase and $\alpha$-fucosidase activities. Strain LHW $37^{\mathrm{T}}$ was positive for the reduction of nitrate to nitrite, D-glucose fermentation and gelatin hydrolysis (API 20NE). Closely related species within the genus Neptunomonas gave markedly different results in the biochemical tests (Table 1).

For cellular fatty acid analysis, strain LHW $37^{\mathrm{T}}$ and three closely related reference strains (N. japonica JAMM $0745^{\mathrm{T}}$, $N$. antarctica $\mathrm{S} 3-22^{\mathrm{T}}$ and $N$. naphthovorans $\mathrm{NAG}-2 \mathrm{~N}-126^{\mathrm{T}}$ ) were cultivated on MA supplemented with $2 \%(w / v) ~ \mathrm{NaCl}$ at $20{ }^{\circ} \mathrm{C}$ for 2 days. Cellular fatty acids were extracted using the standard protocol of the Microbial Identification System (MIDI) and identified using the Microbial Identification software package (Sasser, 1990). Isoprenoid quinones were extracted with chloroform/methanol $(2: 1, \mathrm{v} / \mathrm{v})$ according to the method of Collins \& Jones (1981a), purified by onedimensional TLC on a silica gel $60 \mathrm{~F}_{254}$ plate (Farcot et al., 1988) and identified by HPLC (Collins \& Jones, 1981b) using a $250 \times 4.6 \mathrm{~mm}$ reverse-phase column (Hypersil ODS, Thermo Scientific). Polar lipids were extracted according to the method of Xin et al. (2000), separated by two-dimensional TLC (Farcot et al., 1988) and detected using the appropriate spray reagents, as described by Tindall (1990). The predominant cellular fatty acids were identified as $\mathrm{C}_{18: 1} \omega 7 c(39.9 \%)$ and summed feature $3\left(\mathrm{C}_{16: 1} \omega 7 c\right.$ and/or iso- $\mathrm{C}_{15: 0} 2-\mathrm{OH} ; 38.0 \%$ ) (Table 2 ). The cellular fatty acid pattern of strain LHW $37^{\mathrm{T}}$ was similar to those of the established species in the genus Neptunomonas. The predominant ubiquinone of strain LHW37 $7^{\mathrm{T}}, \mathrm{Q}-8$, is also a major quinone of $N$. japonica JAMM $0745^{\mathrm{T}}$ (Miyazaki et al., 2008) and $N$. antarctica $\mathrm{S} 3-22^{\mathrm{T}}$ (Zhang et al., 2010). The polar lipid profile of strain LHW $37^{\mathrm{T}}$ comprised phosphatidylethanolamine, phosphatidylglycerol and two unidentified lipids (Fig. S1, available in IJSEM Online).

The 16S rRNA gene of strain LHW $37^{\mathrm{T}}$ was amplified by colony PCR using a PCR pre-mix (WizBio) and the two universal primers $8 \mathrm{~F}$ ( $5^{\prime}$-AGAGTTTGATCCTGGCTCAG$\left.3^{\prime}\right)$ and 1522R (5'-AAGGAGGTGATCCAGCCGC-3'). The PCR product was purified using a QIAquick PCR purification kit (Qiagen) and then sequenced using the BigDye Terminator Cycle Sequencing Ready Reaction kit
Table 2. Cellular fatty acid contents (\%) of strain LHW3 $7^{\top}$ and established species in the genus Neptunomonas

Strains: 1 , LHW $37^{\mathrm{T}} ; 2$, N. japonica JAMM $0745^{\mathrm{T}} ; 3$, N. antarctica S3$22^{\mathrm{T}} ; 4$, N. naphthovorans NAG-2N-126 ${ }^{\mathrm{T}}$. All data from this study. TR, trace $(<1.0 \%)$; ND, not detected; ECL, equivalent chain-length.

\begin{tabular}{|lrccc|}
\hline Fatty acid & $\mathbf{1}$ & $\mathbf{2}$ & $\mathbf{3}$ & $\mathbf{4}$ \\
\hline $\mathrm{C}_{10: 0}$ & 2.9 & 2.9 & $\mathrm{TR}$ & $\mathrm{ND}$ \\
$\mathrm{C}_{10: 0} 3-\mathrm{OH}$ & 5.1 & 4.8 & 4.5 & 6.1 \\
$\mathrm{C}_{12: 0}$ & 1.3 & 1.7 & $\mathrm{TR}$ & 3.7 \\
$\mathrm{C}_{16: 0}$ & 8.7 & 7.0 & 14.7 & 17.1 \\
$\mathrm{C}_{17: 0}$ cyclo & $\mathrm{ND}$ & $\mathrm{ND}$ & $\mathrm{ND}$ & 1.5 \\
$\mathrm{C}_{18: 1} \omega 7 c$ & 39.9 & 32.5 & 9.9 & 34.3 \\
$10-$ Methyl C $19: 0$ & 1.4 & 2.4 & $\mathrm{ND}$ & $\mathrm{ND}$ \\
Summed feature 3* & 38.0 & 45.2 & 64.0 & 37.9 \\
Unknown ECL 11.799 & 2.8 & 4.3 & 4.5 & 2.0 \\
& & & & \\
\hline
\end{tabular}

${ }^{*}$ Summed features represent groups of two or more fatty acids that could not be separated by GLC with the Microbial Identification System. Summed feature 3 contained $\mathrm{C}_{16: 1} \omega 7 c$ and/or iso- $\mathrm{C}_{15: 0} 2$ $\mathrm{OH}$.

(Applied Biosystems) and an ABI PRISM 3730xl automated DNA analyser (Applied Biosystems). The sequence fragments were assembled, using the SeqMan software package (DNASTAR), to obtain a nearly full-length $16 \mathrm{~S}$ rRNA gene sequence. This sequence was then compared with the 16S rRNA gene sequences of type strains of established species, using the EzTaxon-e server (Kim et al., 2012). It was then aligned with the $16 \mathrm{~S}$ rRNA gene sequences of the species that appeared to be most closely related to strain LHW $37^{\mathrm{T}}$, using CLUSTAL $\mathrm{w}$ (Thompson et al., 1994). The quality of the $16 \mathrm{~S}$ rRNA gene sequences was confirmed using the BioEdit software package (Hall, 1999). Phylogenetic trees based on 16S rRNA gene sequences were generated using MEGA5 (Tamura et al., 2011) and the neighbour-joining (Saitou \& Nei, 1987), maximum-parsimony (Kluge \& Farris, 1969) and maximum-likelihood methods (Felsenstein, 1981). The tree topologies were evaluated using bootstrap analyses, with 1000 replications. A distance matrix was determined using the two-parameter model of Kimura (1980). Strain LHW $37^{\mathrm{T}}$ was found to be most closely related to $N$. japonica JAMM $0745^{\mathrm{T}}$ (97.1\% 16S rRNA gene sequence similarity), $N$. antarctica $33-22^{\mathrm{T}}(96.3 \%)$ and $N$. naphthovorans NAG-2N$126^{\mathrm{T}}(95.3 \%)$. In the phylogenetic trees, the novel strain clustered with these three established species belonging to the genus Neptunomonas (Fig. 1).

For the determination of $\mathrm{G}+\mathrm{C}$ contents and/or for DNA-DNA hybridization experiments, genomic DNA was extracted from strain LHW $37^{\mathrm{T}}$ and its closest relative (N. japonica JAMM $0745^{\mathrm{T}}$ ) by using the G-spin genomic DNA extraction kit (iNtRON Biotechnology). DNA-DNA hybridization experiments were conducted using genomeprobing microarrays (Bae et al., 2005; Chang et al., 2008), with DNA-DNA relatedness values calculated from the 


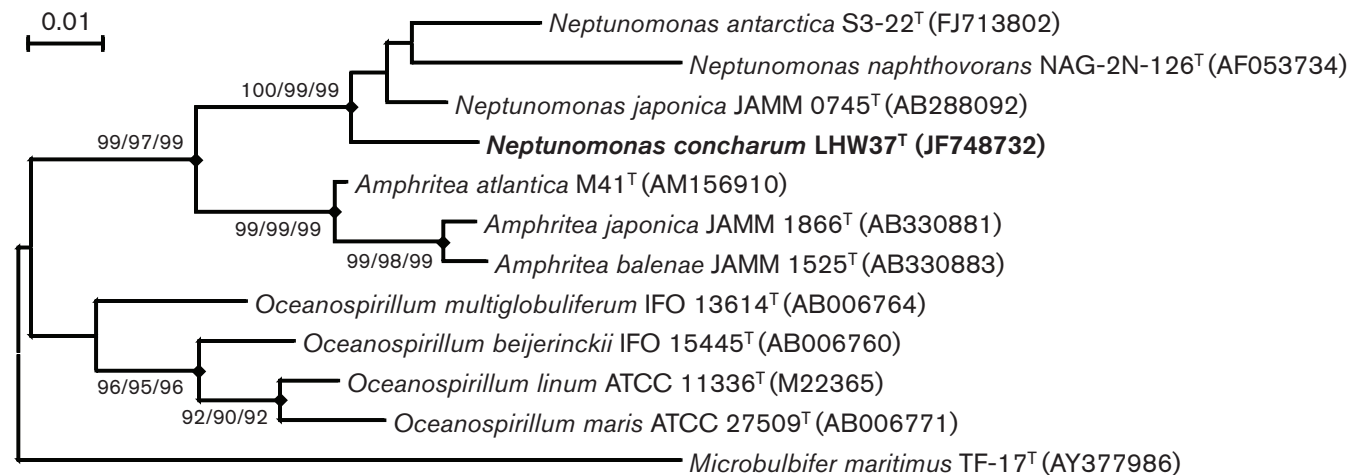

Fig. 1. A neighbour-joining phylogenetic tree based on 16S rRNA gene sequences showing the relationship between strain LHW $37^{\top}$ and its phylogenetic neighbours, including the established species in the genus Neptunomonas. Bootstrap values (neighbour-joining/maximum-parsimony/maximum-likelihood) $>70 \%$ (each based on 1000 replications) are shown at branch points. Filled diamonds indicate that the corresponding nodes were obtained using all three tree-making methods. Microbulbifer maritimus TF- $17^{\top}$ was used as an outgroup. Bar, 0.01 substitutions per nucleotide position.

signal-to-noise ratios of the probes (Loy et al., 2005). The mean DNA-DNA relatedness values recorded between strain LHW $37^{\mathrm{T}}$ and N. japonica JAMM $0745^{\mathrm{T}}-18 \%$ and, in the reciprocal hybridization, $6 \%$ - fell well below the threshold value of $70 \%$ (Stackebrandt \& Goebel, 1994), that might indicate that these two strains belonged to the same species. The genomic DNA G $+C$ content of the novel strain was determined using SYBR Gold I (Life Technologies) and a real-time PCR thermocycler (Gonzalez \& Saiz-Jimenez, 2002), with samples of genomic DNA from Escherichia coli $\mathrm{K}-12$, Ruegeria pomeroyi DSS- $3^{\mathrm{T}}$ and Ruminococcus obeum ATCC $29174^{\mathrm{T}}$ used for reference. The genomic DNA G + C content of strain LHW $37^{\mathrm{T}}, 48.2 \mathrm{~mol} \%$, fell within the range shown by established species belonging to the genus Neptunomonas (Hedlund et al., 1999).

Based on the results of phenotypic, genotypic and phylogenetic analyses, strain LHW $37^{\mathrm{T}}$ represents a novel species within the genus Neptunomonas, for which the name Neptunomonas concharum sp. nov. is proposed.

\section{Emended description of the genus Neptunomonas}

The description of the genus Neptunomonas is based on that given previously by Hedlund et al. (1999) but with the following change. The major polar lipids include phosphatidylethanolamine and phosphatidylglycerol.

\section{Description of Neptunomonas concharum sp. nov.}

Neptunomonas concharum (con.cha'rum. L. gen. pl. n. concharum of bivalves, of shellfish, indicating the type of animal from which the species was isolated).

The cells are motile, Gram-staining-negative, facultatively anaerobic rods that measure $1.0-1.2 \times 0.5-0.6 \mu \mathrm{m}$.
Colonies formed after incubation for 2 days on MA at $37{ }^{\circ} \mathrm{C}$ are cream-coloured, circular, $0.5-2.0 \mathrm{~mm}$ in diameter, smooth and convex. Optimal growth occurs at $\mathrm{pH} 7.0-8.0$, in the presence of $2 \%(\mathrm{w} / \mathrm{v}) \mathrm{NaCl}$, and at $37^{\circ} \mathrm{C}$. Positive for catalase, oxidase and DNase activities and for the assimilation of inulin, 3-methyl glucose, methyl $\beta$-D-glucoside, stachyose, acetic acid, $\beta$-hydroxybutyric acid, $\alpha$-ketovaleric acid, L-malic acid, pyruvic acid methyl ester, succinic acid monomethyl ester, succinamic acid, $\mathrm{N}$ acetyl-L-glutamic acid, L-alanyl glycine, L-asparagine, Lglutamic acid and glycyl L-glutamic acid. Positive (API 20NE and API ZYM) for alkaline phosphatase, leucine arylamidase, naphthol-AS-BI-phosphohydrolase and acid phosphatase activities, reduction of nitrate to nitrite, Dglucose fermentation and gelatin hydrolysis. Acid is produced (in API 50CHB tests) from D-ribose, D-fructose, L-sorbose, D-tagatose, D-arabinose, L-arabinose, D-xylose, L-xylose, aesculin, salicin, turanose, D-lyxose and potassium 5-ketogluconate. The major cellular fatty acids are $\mathrm{C}_{18: 1} \omega 7 c$ and summed feature $3\left(\mathrm{C}_{16: 1} \omega 7 c\right.$ and/or iso$\mathrm{C}_{15: 0}$ 2-OH). The predominant quinone is $\mathrm{Q}-8$. The polar lipid profile comprises phosphatidylethanolamine, phosphatidylglycerol and two unidentified lipids.

The type strain, $\operatorname{LHW} 37^{\mathrm{T}}\left(=\right.$ KACC $\left.15543^{\mathrm{T}}=\mathrm{JCM} 17730^{\mathrm{T}}\right)$, was isolated from a dead ark clam collected on the southern coast of Korea. The genomic DNA G + C content of strain LHW $37^{\mathrm{T}}$ is $48.2 \mathrm{~mol} \%$.

\section{Acknowledgements}

We thank Dr J. P. Euzéby (École Nationale Vétérinaire, France) for his advice on nomenclature. This work was supported by the Republic of Korea's National Institute of Biological Resources and the National Research Foundation of Korea's Mid-career Researcher Program (2011-0028854). The National Research Foundation of Korea is itself funded by the Ministry of Education, Science and Technology. 


\section{References}

Bae, J. W., Rhee, S. K., Park, J. R., Chung, W. H., Nam, Y. D., Lee, I., Kim, H. \& Park, Y. H. (2005). Development and evaluation of genomeprobing microarrays for monitoring lactic acid bacteria. Appl Environ Microbiol 71, 8825-8835.

Chang, H. W., Nam, Y. D., Jung, M. Y., Kim, K. H., Roh, S. W., Kim, M. S., Jeon, C. O., Yoon, J. H. \& Bae, J. W. (2008). Statistical superiority of genome-probing microarrays as genomic DNA-DNA hybridization in revealing the bacterial phylogenetic relationship compared to conventional methods. J Microbiol Methods 75, 523-530.

Collins, M. D. \& Jones, D. (1981a). Distribution of isoprenoid quinone structural types in bacteria and their taxonomic implication. Microbiol Rev 45, 316-354.

Collins, M. D. \& Jones, D. (1981b). A note on the separation of natural mixtures of bacterial ubiquinones using reverse-phase partition thinlayer chromatography and high performance liquid chromatography. J Appl Bacteriol 51, 129-134.

Farcot, J. M., Mercky, F., Tritschler, J. L. \& Schaeffer, F. (1988). Percutaneous cervical chordotomy in primary or secondary chest cancer pains (apropos of 19 cases). Agressologie 29, 87-89 (in French).

Felsenstein, J. (1981). Evolutionary trees from DNA sequences: a maximum likelihood approach. J Mol Evol 17, 368-376.

Gonzalez, J. M. \& Saiz-Jimenez, C. (2002). A fluorimetric method for the estimation of $\mathrm{G}+\mathrm{C}$ mol\% content in microorganisms by thermal denaturation temperature. Environ Microbiol 4, 770-773.

Hall, T. A. (1999). BioEdit: a user-friendly biological sequence alignment editor and analysis program for Windows 95/98/NT. Nucleic Acids Symp Ser 41, 95-98.

Hedlund, B. P., Geiselbrecht, A. D., Bair, T. J. \& Staley, J. T. (1999). Polycyclic aromatic hydrocarbon degradation by a new marine bacterium, Neptunomonas naphthovorans gen. nov., sp. nov. Appl Environ Microbiol 65, 251-259.

Kim, O.-S., Cho, Y.-J., Lee, K., Yoon, S.-H., Kim, M., Na, H., Park, S.-C, Jeon, Y. S., Lee, J.-H., Yi, H., Won, S. \& Chun, J. (2012). Introducing EzTaxon-e: a prokaryotic $16 \mathrm{~S}$ rRNA gene sequence database with phylotypes that represent uncultured species. Int J Syst Evol Microbiol 62, 716-721.

Kimura, M. (1980). A simple method for estimating evolutionary rates of base substitutions through comparative studies of nucleotide sequences. J Mol Evol 16, 111-120.
Kluge, A. G. \& Farris, F. S. (1969). Quantitative phyletics and the evolution of anurans. Syst Zool 18, 1-32.

Loy, A., Schulz, C., Lücker, S., Schöpfer-Wendels, A., Stoecker, K., Baranyi, C., Lehner, A. \& Wagner, M. (2005). 16S rRNA gene-based oligonucleotide microarray for environmental monitoring of the betaproteobacterial order "Rhodocyclales". Appl Environ Microbiol 71, 1373-1386.

Miyazaki, M., Nogi, Y., Fujiwara, Y., Kawato, M., Kubokawa, K. \& Horikoshi, K. (2008). Neptunomonas japonica sp. nov., an Osedax japonicus symbiont-like bacterium isolated from sediment adjacent to sperm whale carcasses off Kagoshima, Japan. Int J Syst Evol Microbiol 58, 866-871.

Saitou, N. \& Nei, M. (1987). The neighbor-joining method: a new method for reconstructing phylogenetic trees. Mol Biol Evol 4, 406425.

Sasser, M. (1990). Identification of bacteria by gas chromatography of cellular fatty acids, MIDI Technical Note 101. Newark, DE: MIDI Inc.

Stackebrandt, E. \& Goebel, B. M. (1994). Taxonomic note: a place for DNA-DNA reassociation and 16S rRNA sequence analysis in the present species definition in bacteriology. Int J Syst Bacteriol 44, 846849.

Tamura, K., Peterson, D., Peterson, N., Stecher, G., Nei, M. \& Kumar, S. (2011). MEGA5: molecular evolutionary genetics analysis using maximum likelihood, evolutionary distance, and maximum parsimony methods. Mol Biol Evol 28, 2731-2739.

Thompson, J. D., Higgins, D. G. \& Gibson, T. J. (1994). CLUSTAL W: improving the sensitivity of progressive multiple sequence alignment through sequence weighting, position-specific gap penalties and weight matrix choice. Nucleic Acids Res 22, 4673-4680.

Tindall, B. J. (1990). Lipid composition of Halobacterium lacusprofundi. FEMS Microbiol Lett 66, 199-202.

Tittsler, R. P. \& Sandholzer, L. A. (1936). The use of semi-solid agar for the detection of bacterial motility. J Bacteriol 31, 575-580.

Xin, H., Itoh, T., Zhou, P., Suzuki, K., Kamekura, M. \& Nakase, T. (2000). Natrinema versiforme sp. nov., an extremely halophilic archaeon from Aibi salt lake, Xinjiang, China. Int J Syst Evol Microbiol 50, 1297-1303.

Zhang, X. Y., Zhang, Y. J., Yu, Y., Li, H. J., Gao, Z. M., Chen, X. L., Chen, B. \& Zhang, Y. Z. (2010). Neptunomonas antarctica sp. nov., isolated from marine sediment. Int J Syst Evol Microbiol 60, 19581961. 